\title{
Üniversite Öğrencileri Açısından Kentsel Kültürel Peyzajlarda Karakter ve Algı Değişimi: Bartın, Amasra, Safranbolu*
}

\author{
Bülent CENGIZZ*1 , Canan CENGİZ ${ }^{1}$, Pelin KEÇECIOĞLU DAĞLI ${ }^{1}$ \\ ${ }^{1}$ Bartın Üniversitesi, Orman Fakültesi, Peyzaj Mimarlığı Bölümü, 74100, Bartın, Türkiye \\ * Corresponding Author: bcengiz@bartin.edu.tr
}

Geliş tarihi: 08.09.2016

Kabul Tarihi:15.12.2016

Özet: Yüzyıllar boyunca birçok medeniyete ev sahipliği yapmış olan Anadolu sahip olduğu peyzaj çeşitliliği ile günümüzde kültürel peyzajlar açısından önemli örneklere sahiptir. Bu örnekler içerisinde ülkemizde Batı Karadeniz Bölgesi’ndeki kültürel turizm tur güzergahında yer alan araştırma alanları olarak seçilen Bartın, Amasra ve Safranbolu kentleri kendilerine özgü kültürel peyzaj karakterleri ile dikkat çekmektedir. Günümüzdeki hızlı kentleşme, kültürel peyzajlar üzerinde baskılar oluşturmaktadır ve beraberinde değişimi getirmektedir. $\mathrm{Bu}$ kapsamda, seçilen alanlarda kentsel kültürel peyzaj karakterindeki değişim algısı Bartın Üniversitesi Peyzaj Mimarlığı Bölümü 3. ve 4. sınıf lisans öğrencileri ile lisansüstü öğrencilerine anket uygulanarak ortaya konulmuştur. Anket sonuçlarına göre öğrencilerinin seçilen kentler bütününde kültürel peyzajlardaki karakter değişimindeki farkındalıklarının yüksek olduğu ortaya çıkmıştır. Gerek bakımsızlık gerek peyzaj onarım çalışmalarının eksikliği gerekse tarihi dokuyla uyumsuz planlamalar ve tasarımlar açısından kentsel kültürel peyzaj karakterinin geçmişten günümüze olumsuz bir değişim süreci sergilediği katılımcı değerlendirmeleri sonucunda elde edilmiştir. Anket sonucunda, katılımcılar genel olarak Bartın Çayı'nın Bartın Kenti için önemli bir karakter ögesi olduğunu ama sel ve taşkın riski açısından Bartın Çayı ve çevresinin yeniden planlanması gerektiğini ve tarihi Bartın evlerinin mevcut haliyle terkedilmiş bir görünüme sahip olduğunu ifade etmişlerdir. Amasra içinse Amasra'nın tarihi arkeolojik antik liman karakterini yansıttığı ve kentin yarımada özelliğinin görsel ve estetik çeşitlilik sunduğu ifade edilirken, kentsel sit alanı içerisindeki yeni yapıların geleneksel konut dokusu ile uyumlu olmadığı katılımcılar tarafından ortaya konulan sonuçlar arasındadır. Son olarak Safranbolu için Safranbolu evlerinin Safranbolu Kenti için önemli bir karakter ögesi olduğunu, safranın Safranbolu için karakteristik bir bitki olduğunu ve geleneksel kent dokusunun mevcut haliyle kente kültürel ve estetik bir görünüm kazandırdığını ifade ederken, kent dokusundaki mevcut açık ve yeşil alanların nitelik ve nicelik yönünden yeterli olmadığını belirtmişlerdir. Üniversite öğrencilerinin algıları ve tercihleri göz önünde bulundurulduğunda, kent kimliğine ve karakterine uygun gelecekte yapılacak planlama ve tasarım çalışmalarının kentsel kültürel peyzajların miras alanı olarak sürdürülebilirliği açısından önem taşıdığı söylenebilmektedir. Sonuçta, çalışma, Bartın, Amasra ve Safranbolu için yapı ölçeğinden kent ölçeğine kadarki kentsel tasarım stratejilerinin geliştirilmesi açısından önemli bir yol gösterici özelliğe sahiptir.

Anahtar Kelimeler: Kültürel Peyzaj, Peyzaj Karakteri, Peyzaj Algısı, Kullanıcı Algısı

Character and Perception Changes in the Urban Cultural Landscape in terms of University Students: Bartın, Amasra and Safranbolu, Turkey

Abstract: Anatolia had hosted many civilizations. It has important examples of cultural landscape diversity. Of them, the cities of Bartın, Amasra and Safranbolu were selected as research areas because of the character of their unique cultural landscapes, and because they are located on the cultural tourism itineraries in Turkey's Western Black Sea Region. Today's rapid urbanization pits pressure on cultural landscapes. Perceptions of changes in the character of the urban cultural landscape in the selected cities were determined by administering a questionnaire to Bartın University's Department of Landscape Architecture third year, fourth year and postgraduate students. The participants stated that the Bartın River was an important element of Bartın's character, but that the Bartın River and its environment need to be re-planned for flood risk, and that the historical Bartın houses have a desolate view. The participants revealed that Amasra showed historical and archaeological antique dock characteristics and had visual variety due to its location on a peninsula. However, they said that new buildings in an urban protected area are not compatible with the traditional ones. Finally, their opinions about Safranbolu were presented by the participants as Safranbolu houses were important elements of Safranbolu's character, that saffron was a characteristic plant of Safranbolu and that the current state of the traditional urban pattern gave the city a cultural distinctiveness and an aesthetic appearance. However, they stated that there was not enough open green space in the urban pattern. The perceptions and preferences of university students indicate that the planning and design work appropriate to the urban identity and character are important for the sustainability of urban cultural landscape heritage. In conclusion, the study offers important guidance for Bartın, Amasra and Safranbolu in terms of developing urban design strategies from structure to urban scale.

Keywords: Cultural Landscape, Landscape Character, Landscape Perception, User Perception 


\section{Giriş}

Avrupa Peyzaj Sözleşmesi'ne göre peyzaj, insanlar tarafından algılandığ 1 şekliyle, karakteri doğal ve/veya insani unsurların eyleminin ve etkileşiminin sonucu olan bir alan olarak tanımlanmaktadır (URL1). Bu çerçevede, kültürel peyzaj, insanların doğayı çeşitli amaçlarla kullanmaları sonucu ortaya çıkan bir peyzaj türüdür. Doğa ile insanların etkileşimi sonucunda şekillenen kültürel peyzajlar, yap1 ölçeğinden kent ölçeğine kadar farklı büyüklüklerdeki alanları kapsayabilmektedir (EHLA, 2014). Kentsel kültürel peyzajlar ise kent içerisindeki tarihsel ve geleneksel özellikleriyle miras değerine sahip olan, bulunduğu yerin yaşam kültürünün ve kurgusunun izlerini taşıyan peyzajlardır (Çetinkaya ve Uzun, 2014). Peyzajlar yüzyıllardır üstüste konan ve süregelen doğal ve kültürel değişimlerin bir sonucu olduğundan, kentsel kültürel peyzajları değerlendirebilmek için tarihi bir bakış açısı gerekmektedir (Bürgi et al., 2004). Kentsel kültürel peyzajda kimliği oluşturan sembol ve mekanların sürekliliğinin sağlanması, arazi formuyla kent dokusunun ortaya koyduğu kentsel siluetlerinin korunmas1 önem taşımaktadır. Taşıdıkları tarihi ve kültürel önem ve değer bakımından UNESCO tarafindan koruma altına alınan bir çok kent bulunmaktadır.

Sosyal ve ekonomik faktörlerin etkilediği kentleşme süreci, var olan geleneksel peyzaj çeşitliliğini olumsuz yönde etkileyerek homojenleşmesine neden olmaktadır. Hızlı ve kontrolsüz kentleşme, sosyal ve mekânsal parçalanmalara neden olmakta, kentsel çevre kalitesini düşürmekte, kentsel tarihi ve kültürel peyzajları olumsuz yönde etkilemektedir. Mekânsal ve çevresel planlamalar, peyzaj karakterindeki değişimi durduramamaktadır. Kültür peyzajı değiştirmekte ve kültür peyzaj ile şekillenmektedir (Nassauer, 1995; Antrop, 2004). Bu nedenle, peyzaj değişimi, peyzajın doğa olayları ve insan müdahaleleriyle mekân ve zaman boyutunda farklı bir karakter göstermesi olarak tanımlanmaktadır (Şahin ve ark., 2013). Kentleşme süreci de bireylerin yaşam biçimlerini değiştirdiğinden bu durum kentin morfolojisini ve üstlendiği fonksiyonları da etkilemektedir. Bir peyzajda kalıc1 bulunan farklı ve algilanabilir elementlerin oluşturduğu desen ve bunların insanlar tarafından nasıl algılandığını ifade eden peyzaj karakterinin (Şahin ve ark., 2013) bulunduğu, bir peyzaji diğer peyzajdan iyi ya da kötü yönde ayıran ve farklı kılan unsurların bütünü olarak tanımlanan peyzaj karakter alanları da (Tudor, 2014) değişimden etkilenmektedir. Kültürel peyzaj karakter alanları bulunduğu kente ekonomik yarar sağlamakla birlikte kentleşme ve turizm baskısı sebebiyle karakterinin bozulabileceğinin göz önünde bulundurulması gereken alanlardır. Önemli doğal ve kültürel peyzaj karakterlerine sahip olan alanların yaşam kalitesini arttırmak, kültürel ve tarihi dinamiklerini korumak için yapılacak olan peyzaj planlama ve tasarım çalışmalarında bu değerlerinin göz önünde bulundurulması gerekmektedir (UNESCO, 2011). Kültürel mirası koruma çalışmaları ülkemizde artan öneme sahiptir. Örneğin İstanbul Tarihi Yarımada, Safranbolu, Mardin, Beypazarı (Ankara), Hamamönü (Ankara) vb. kentsel sit alanlarında bu uygulamalar yapılmaktadır (Kurtar ve Somuncu, 2013).

Alanların değişme potansiyelleri, kent içerisinde bulunduğu önem yerine, zamana ve ölçeğine göre farklılık göstermektedir. Bazı alanlar hızlı bazı alanlar ise yavaş yavaş değişmektedir (Bürgi et al., 2004). Kültürel peyzaj karakterinin algilanması bireylerdeki değer sıralamasındaki farklılık ve kültürel doku ile ilgili farklı anlam birikimi düzeyi nedeniyle farklılaşmaktadır (Hunziker et al., 2008). Doğal ve kültürel peyzaj dokularının sürdürülebilirliği açısından, karakterlerin tanımlanmasında, bu karakterlerin değerlerinin ve değişimlerinin ölçülmesinde, duyular yoluyla bilgi edinimini sağlayan araçların başında gelen görme duyusunun etkinliği bir ölçüt olarak kullanılmaktadır. $\mathrm{Bu}$ kapsamda, kentsel tasarım çalışmalarında görsel alg1 ve görsel peyzaj çalışmaları yapilmaktadır (Bulut and Yılmaz, 2008; Ak, 2013). Kentin algilanmasındaki, kentin kimliğinin ve imajının oluşmasındaki kentsel tasarım yaklaşımı bu şekilde tanımlanmaktadır. Çevresel gelişim, kültürel aktiviteler, görsel alg1 ve kentsel tasarım stratejilerinin oluşturulmasında peyzaj bütünlüğü içinde kenti oluşturan ögelerin 
değerlendirilmesi gerekmekte ve sürece halkın katılımı da dahil edilmektedir (Erdoğan, 2006; Tveit et al., 2006; Cengiz and Keçecioğlu, 2014). Örneğin Bizerril'in 2004'teki çalışmasında Brezilya'daki Cerrado peyzajlarının farkındalığını ölçmek üzere yaşları 11-17 arasında değişen farklı sosyal sınıflardaki öğrencilerin bilgi birikimi ve algısı irdelenmiştir. Çalışmada, bölgenin peyzajıyla daha çok ilişki içerisinde olanın farkındalığının yüksek olduğu tespit edilmiştir. Ek olarak, okullarda verilen eğitimin de çevre duyarlılığına etkisi olduğu belirtilerek bölgenin peyzajının tam anlamıla bilinmesi için verilen derslerin öneminden bahsedilmiştir. Hunziker ve arkadaşları (2008) ise İsviçre'nin Alplerindeki peyzaj değişiminin alanın içinde ya da dışında yaşayan farklı sosyal statüde olanlar tarafindan farklı algilanıp yorumlansa da değişimin fark edildiği ve bu değişime bireylerin kolaylıkla adapte olduğundan bahsetmiştir.

Yüzyıllar boyunca birçok medeniyete ev sahipliği yapmış olan Anadolu sahip olduğu peyzaj çeşitliliği ile günümüzde kültürel peyzajlar açısından önemli örneklere sahiptir.
$\mathrm{Bu}$ örnekler içerisinde çalışma alanı olarak seçilen Bartın, Amasra ve Safranbolu kentleri kendilerine özgü peyzaj karakterleri ile dikkat çekmektedir. Bu nedenle, ülkemizde Batı Karadeniz Bölgesi'ndeki kültürel turizm tur güzergâhında yer alan üç kent araştırma alanları olarak seçilmiştir. Günümüzdeki hızlı kentleşme, kültürel peyzajlar üzerinde baskılar oluşturmaktadır ve beraberinde değişimi getirdiği için seçilen alanlarda kentsel kültürel peyzaj karakterindeki değişim algisı Bartın Üniversitesi Peyzaj Mimarlığı Bölümü öğrencilerine anket uygulanarak ortaya konulmuştur.

\section{Materyal ve Yöntem}

\section{Materyal}

Çalışmanın ana materyalini Türkiye'nin Batı Karadeniz Bölgesi'nde bulunan, kendilerine özgü kültürel peyzaj karakterleri ile dikkat çeken ve kültürel turizm tur güzergâhında yer alan Safranbolu, Bartın ve Amasra kentleri oluşturmaktadır (Şekil 1). Safranbolu, Bartın ve Amasra kentlerine ilişkin genel peyzaj karakterleri Tablo 1'de sunulmaktadır.

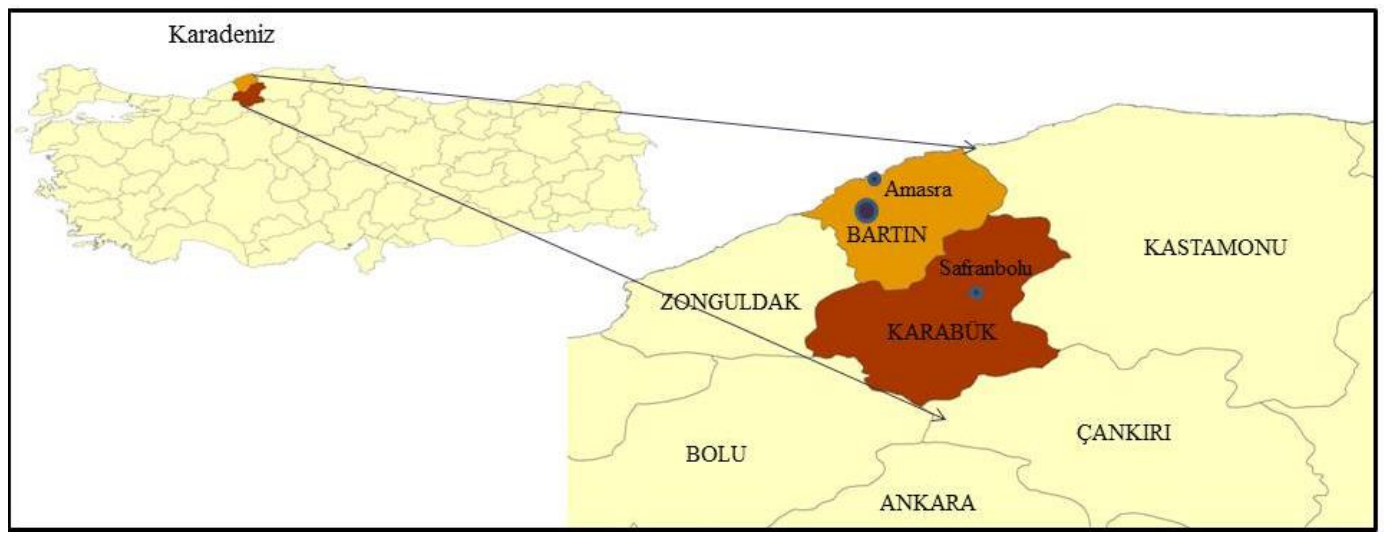

Şekil 1. Çalışma alanlarının konumu 
Tablo 1. Bartın, Amasra ve Safranbolu kentlerinin genel peyzaj karakterleri

\begin{tabular}{|c|c|}
\hline Araşt & Araştırma Alanlarına İlişkin Genel Peyzaj Karakterleri \\
\hline & $\begin{array}{l}\text { - Bartın Çayı vasıtasıyla Bartın kent merkezinin Karadeniz'e } 12 \text { km'lik } \\
\text { doğal su yolu özelliği ile bağlandığı ve akarsu ulaşımına elverişli olan } \\
\text { Bartın kenti Türkiye'de ender kentlerden birisidir (Cengiz, 2007). } \\
\text { - Tarihi geleneksel Bartın evleri, kentsel sit alanı ve doğal sit alanı } \\
\text { varlı̆̆ı ile dikkat çekmektedir (Cengiz, 2007). } \\
\text { - } 2000 \text { yılında Tarihi Kentler Birliği'ne üye olmuştur (URL3). }\end{array}$ \\
\hline Am & $\begin{array}{l}\text { - Tarihi-arkeolojik antik liman kenti özelliği ile dikkat çeken Amasra } \\
\text { (Cengiz ve Cengiz, 2016), yarımada konumundadır (Cengiz and } \\
\text { Keçecioğlu, 2014). } \\
\text { - Tarihi ve kültürel peyzaj değerleri ve plajları sayesinde turizm } \\
\text { açısından önemli bir çekim merkezidir (Türker ve Çetinkaya, 2009). } \\
\text { - } 2013 \text { yılından bu yana UNESCO Dünya Miras Geçici Listesi'nde yer } \\
\text { almaktadır (URL4). }\end{array}$ \\
\hline 8 & $\begin{array}{l}\text { - Safranbolu, önemli sivil mimari yapılarının, tarihi eserlerinin, doğal } \\
\text { ve kültürel peyzaj karakterine sahiptir (Cengiz and Aşkın, 2015). } \\
\text { - Adını rengi, kokusu ve ekonomik değeri açısından oldukça önemli bir } \\
\text { bitki olan ve Türkiye'de yalnızca bu yörede yetişmekte olan } \\
\text { Safran'dan (Corocus sativa) almaktadır. } \\
\text { - } 1994 \text { yılında UNESCO tarafından nadir ve evrensel kültürel varlıkları } \\
\text { bakımından Dünya Miras Listesi'ne alınmıştır (URL2). }\end{array}$ \\
\hline
\end{tabular}

Konu ile ilgili yerli ve yabanc1 yazılı ve görsel literatür ile SPSS Statistics 22 programı araştırmanın diğer materyallerini oluşturmaktadır.

\section{Yöntem}

Seçilen alanlarda kentsel kültürel peyzaj karakterindeki değişim algısının belirlenmesi için Bartın Üniversitesi Peyzaj Mimarlığ Bölümü öğrencilerine uygulanan anket çalışması iki bölümden oluşmaktadır. Birinci bölüm sosyo-demografik yapıya ilişkin 5 sorudan oluşmaktadır. İkinci bölüm ise alanlara ait sorulardan oluşmaktadır. $\mathrm{Bu}$ bölüm, mevcut duruma ilişkin görüşleri saptamak amaciyla 10 soru ve kullanıc1 taleplerinin ortaya konulmasina yönelik görüşleri saptamak amaciyla 4 soru olmak üzere toplam 14 soruyu içermektedir. İkinci bölüme ait 14 soru araştırma alanı olarak seçilen 3 kent için ayrı ayrı sorularak toplamda 42 soru ile katılımcıların görüşleri alınmıştır. Anketin bütünü ise toplam 47 sorudan oluşmaktadır.
Anket 2014-2015 Bahar Dönemi'nde ve sınıf ortamında birebir uygulanmıştır. Ankete; Bartın Üniversitesi Orman Fakültesi Peyzaj Mimarlığı Bölümü'nde öğrenim gören 52'si üçüncü sınıf, 55'i dördüncü sınıf ve Bartın Üniversitesi Fen Bilimleri Enstitüsü Peyzaj Mimarlı̆̆ Anabilim Dalı'nda öğrenim gören 20'si lisansüstü olmak üzere toplam 127 öğrenci katılmıştır. Anketteki mevcut duruma ilişkin görüşlerin saptanmas1 kısmında her kente ait mevcut durumu ortaya koyan fotoğraflar projeksiyon yardımıyla gösterilmiştir. $\mathrm{Bu}$ fotoğraflar üzerinden katılımcılara likert ölçeği analizine göre sorgulamalar yaptırılmıştır. Katılımcılar her soru için likert ölçeğindeki kesinlikle katılıyorum (5)'den kesinlikle katılmiyorum (1)'e doğru sıralanan yanıtlardan birini tercih ederek cevaplamalar yapmışlardır. Anketlerin değerlendirilmesinde SPSS Statistics 22 programı kullanılmıştır. Güvenirlik Analizi, Frekans Analizi ve KiKare Testi uygulanmıştır. Güvenirlik Analizi sonucunda Cronbach's Alpha güvenirlik katsayıs1 0,842 olarak bulunmuştur. $\mathrm{Bu}$ 
sonuca göre yapılan anket çalışmasının güvenilir sonuçlara sahip olduğu ortaya konmuştur. Frekans Analizi, her bir değişkenin sıklığını (ilgili kategoriye düşen birey sayıs1) ve yüzdesini (sıklığın yüzde olarak ifadesini) bulmak için kullanılmıştır. İki görüş olarak sınıflandırılan değişkenler değerlendirilerek, aralarındaki ilgi derecesinin saptanmas1, aralarında anlamlı bir ilişkinin olup olmadığı açısından ise KiKare Testi uygulanmıştır (Can, 2014).

\section{Bulgular}

\%63,8'i (n:81) bayan, \%36,2'si (n:46) erkek olan katılımcıların her üç kent için görüşleri Frekans Analizi ve Ki-Kare Testine göre değerlendirilmiştir.

\section{Frekans analizi bulguları}

Frekans analizine göre katılımcılar, Bartın Çayı'nın Bartın Kenti için önemli bir karakter ögesi olduğunu, sel ve taşkın riski açısından Bartın Çayı ve çevresinin yeniden planlanması gerektiğini ve tarihi Bartın evlerinin mevcut haliyle terkedilmiş bir görünüme sahip olduğunu ifade etmişlerdir. Ancak, kentsel sit alanı içerisindeki yeni yapıların geleneksel kent dokusu ile uyumlu olmadığını, kent dokusundaki mevcut açık ve yeşil alanların nitelik ve nicelik yönünden yeterli olmadığını ve kültürel kimliğin yıllar geçtikçe değiştiğini belirtmişlerdir (Tablo 2).

Tablo 2. Bartın Kenti'ne ait mevcut duruma ilişkin anket sonuçları

\begin{tabular}{|c|c|c|c|c|c|c|c|c|c|c|}
\hline \multirow{2}{*}{$\begin{array}{l}\text { Mevcut Duruma } \\
\text { Görüsşler }\end{array}$} & \multicolumn{2}{|c|}{$\begin{array}{l}\text { Kesinlikle } \\
\text { Katılıyorum }\end{array}$} & \multicolumn{2}{|c|}{ Katılıyorum } & \multicolumn{2}{|c|}{$\begin{array}{l}\text { Kararsızım/ } \\
\text { Fikrim yok }\end{array}$} & \multicolumn{2}{|c|}{ Katılmıyorum } & \multicolumn{2}{|c|}{$\begin{array}{l}\text { Kesinlikle } \\
\text { Katılmıyorum }\end{array}$} \\
\hline & $\mathbf{n}$ & $\%$ & $\mathbf{n}$ & $\%$ & $\mathbf{n}$ & $\%$ & $\mathbf{n}$ & $\%$ & $\mathbf{n}$ & $\%$ \\
\hline $\begin{array}{l}\text { Bartın Çayı Bartın Kenti için } \\
\text { önemli bir karakter ögesidir. }\end{array}$ & 97 & 76.4 & 26 & 20.5 & 1 & 0.8 & 2 & 1.6 & 1 & 0.8 \\
\hline $\begin{array}{l}\text { Bartın Çayı çeşitli rekreasyonel } \\
\text { aktiviteler için olanak sunmaktadır } \\
\text { (tekne turu, balıkçılık). }\end{array}$ & 35 & 27.6 & 54 & 42.5 & 10 & 7.9 & 23 & 18.1 & 5 & 3.9 \\
\hline $\begin{array}{l}\text { Bartın Çayı mevcut haliyle kente } \\
\text { doğal ve estetik bir görünüm } \\
\text { kazandırmaktadır. }\end{array}$ & 24 & 18.9 & 50 & 39.4 & 14 & 11 & 29 & 22.8 & 10 & 7.9 \\
\hline $\begin{array}{l}\text { Kentsel sit alanı içerisindeki yeni } \\
\text { yapılar geleneksel kent dokusu ile } \\
\text { uyumludur. }\end{array}$ & 7 & 5.5 & 7 & 5.5 & 21 & 16.5 & 65 & 51.2 & 27 & 21.3 \\
\hline $\begin{array}{l}\text { Bartın Çayı'nın her iki kıyısındaki } \\
\text { koridor doğal sit özelliğini } \\
\text { yansıtmaktadır. }\end{array}$ & 24 & 18.9 & 45 & 35.4 & 22 & 17.3 & 30 & 23.6 & 6 & 4.7 \\
\hline $\begin{array}{l}\text { Sel ve taşkın riski açısından Bartın } \\
\text { Çayı ve çevresi yeniden } \\
\text { planlanmalıdır. }\end{array}$ & 95 & 74.8 & 25 & 19.7 & 2 & 1.6 & 3 & 2.4 & 2 & 1.6 \\
\hline $\begin{array}{l}\text { Tarihi Bartın evleri mevcut haliyle } \\
\text { terkedilmiş bir görünüme sahiptir. }\end{array}$ & 50 & 39.4 & 45 & 35.4 & 14 & 11 & 14 & 11 & 4 & 3.1 \\
\hline $\begin{array}{l}\text { Kent dokusundaki açık ve yeşil } \\
\text { alanlar nitelik ve nicelik yönünden } \\
\text { yeterlidir. }\end{array}$ & 8 & 6.3 & 25 & 19.7 & 25 & 19.7 & 47 & 37 & 22 & 17.3 \\
\hline $\begin{array}{l}\text { Külttürel kimlik değişmeden } \\
\text { günümüze kadar ulaşmıştır }\end{array}$ & 6 & 4.7 & 17 & 13.4 & 33 & 26 & 59 & 46.5 & 12 & 9.4 \\
\hline $\begin{array}{l}\text { Bartın'daki yerleşim } \\
\text { topoğrafya ile uyumludur. }\end{array}$ & 7 & 5.5 & 43 & 33.9 & 26 & 20.5 & 37 & 29.1 & 14 & 11 \\
\hline
\end{tabular}


Aynı analize göre katılımcılar, Amasra Kenti'nin turizmde marka bir kent olduğunu, Amasra'nın tarihi arkeolojik kıyı kenti karakterini yansıttığını ve kentin yarımada özelliğinin görsel ve estetik çeşitlilik sunduğunu ifade etmektedir. Öte yandan, katılımcılar kentsel sit alanı içerisindeki yeni yapıların geleneksel konut dokusu ile uyumlu olmadığııı, kent dokusundaki mevcut açık ve yeşil alanların nitelik ve nicelik yönünden yeterli olmadığını ve kültürel kimliğin değişmeden günümüze kadar ulaştı̆̆ını belirtmişlerdir (Tablo 3).

Tablo 3. Amasra Kenti'ne ait mevcut duruma ilişkin anket sonuçları

\begin{tabular}{|c|c|c|c|c|c|c|c|c|c|c|}
\hline \multirow{2}{*}{$\begin{array}{l}\text { Mevcut Duruma } \\
\text { Görüşsler }\end{array}$} & \multicolumn{2}{|c|}{$\begin{array}{l}\text { Kesinlikle } \\
\text { Katıllyorum }\end{array}$} & \multicolumn{2}{|c|}{ Katılıyorum } & \multicolumn{2}{|c|}{$\begin{array}{l}\text { Kararsızım/ } \\
\text { Fikrim yok }\end{array}$} & \multicolumn{2}{|c|}{ Katılmıyorum } & \multicolumn{2}{|c|}{$\begin{array}{l}\text { Kesinlikle } \\
\text { Katılmıyorum }\end{array}$} \\
\hline & $\mathbf{n}$ & $\%$ & $\mathbf{n}$ & $\%$ & $\mathbf{n}$ & $\%$ & $\mathbf{n}$ & $\%$ & $\mathbf{n}$ & $\%$ \\
\hline $\begin{array}{l}\text { Amasra, tarihi arkeolojik kıyı kenti } \\
\text { karakterini yansıtmaktadır. }\end{array}$ & 74 & 58.3 & 41 & 32.3 & 6 & 4.7 & 5 & 3.9 & 1 & 0.8 \\
\hline $\begin{array}{l}\text { Amasra Kenti turizmde bir marka } \\
\text { kentidir. }\end{array}$ & 68 & 53.5 & 45 & 35.4 & 10 & 7.9 & 4 & 3.1 & - & - \\
\hline $\begin{array}{l}\text { Amasra Kenti gastronomi turizmi } \\
\text { açısından önem taşımaktadır. }\end{array}$ & 34 & 26.8 & 54 & 42.5 & 25 & 19.7 & 9 & 7.1 & 5 & 3.9 \\
\hline $\begin{array}{l}\text { Kentsel sit alanı içerisindeki yeni } \\
\text { yapılar geleneksel kent dokusu ile } \\
\text { uyumludur. }\end{array}$ & 7 & 5.5 & 21 & 16.5 & 29 & 22.8 & 44 & 34.6 & 26 & 20.5 \\
\hline $\begin{array}{l}\text { Tescilli yapılar kent bütününde } \\
\text { yeterince algılanmaktadır (Amasra } \\
\text { Kalesi, Cenova Şatosu, Kemere } \\
\text { Köprüsü, Şapel vb.) }\end{array}$ & 32 & 25.2 & 40 & 31.5 & 13 & 10.2 & 32 & 25.2 & 10 & 7.9 \\
\hline $\begin{array}{l}\text { Büyük Liman ve Küçük Liman kıyı } \\
\text { kullanımları açısından çeşitlilik } \\
\text { sağlamaktadır. }\end{array}$ & 22 & 17.3 & 52 & 40.9 & 26 & 20.5 & 21 & 16.5 & 6 & 4.7 \\
\hline $\begin{array}{l}\text { Amasra Kenti yarımada özelliği ile } \\
\text { görsel ve estetik ç̧ş̧tlilik } \\
\text { sunmaktadır. }\end{array}$ & 75 & 59.1 & 42 & 33.1 & 6 & 4.7 & 2 & 1.6 & 2 & 1.6 \\
\hline $\begin{array}{l}\text { Kent dokusundaki açık ve yeşil } \\
\text { alanlar nitelik ve nicelik yönünden } \\
\text { yeterlidir. }\end{array}$ & 9 & 7.1 & 35 & 27.6 & 27 & 21.3 & 44 & 34.6 & 12 & 9.4 \\
\hline $\begin{array}{l}\text { Kültürel kimlik değişmeden } \\
\text { günümüze kadar ulaşmıştır }\end{array}$ & 11 & 8.7 & 51 & 40.2 & 30 & 23.6 & 26 & 20.5 & 9 & 7.1 \\
\hline $\begin{array}{l}\text { Amasra'daki yerleşim } \\
\text { topoğrafya ile uyumludur. }\end{array}$ & 21 & 16.5 & 67 & 52.8 & 22 & 17.3 & 12 & 9.4 & 5 & 3.9 \\
\hline
\end{tabular}

Katılımcilar Safranbolu evlerinin Safranbolu Kenti için önemli bir karakter ögesi olduğunu, geleneksel kent dokusunun mevcut haliyle kente kültürel ve estetik bir görünüm kazandırdığını, Safranbolu'daki yerleșim dokusunun topoğrafya ile uyumlu olduğunu ve Safranın Safranbolu için karakteristik bir bitki olduğunu ifade etmişlerdir. Katılımcılar aynı kent için kültürel kimliğin yıllar geçtikçe değişmeden günümüze kadar ulaştığını belirtmişlerdir. Öte yandan, üzüm bağları ve orkidenin Safranbolu için bir karakteristik değer olup olmadığ1 ve mevcut olan bağ yerleşimlerinin bakımsız ve terk edilmiş bir halde olup olmadığı konularında kararsız kalmışlardır (Tablo 4). 
Tablo 4. Safranbolu Kenti'ne ait mevcut duruma ilişkin anket sonuçları

\begin{tabular}{|c|c|c|c|c|c|c|c|c|c|c|}
\hline \multirow[b]{2}{*}{$\begin{array}{l}\text { Mevcut Duruma } \\
\text { Görüşler }\end{array}$} & \multicolumn{2}{|c|}{$\begin{array}{l}\text { Kesinlikle } \\
\text { Katılyyorum } \\
\end{array}$} & \multicolumn{2}{|c|}{ Katılıyorum } & \multicolumn{2}{|c|}{$\begin{array}{l}\text { Kararsızım/ } \\
\text { Fikrim yok }\end{array}$} & \multicolumn{2}{|c|}{ Katılmıyorum } & \multicolumn{2}{|c|}{$\begin{array}{l}\text { Kesinlikle } \\
\text { Katılmıyorum }\end{array}$} \\
\hline & $\mathbf{n}$ & $\%$ & $\mathbf{n}$ & $\%$ & $\mathbf{n}$ & $\%$ & $\mathbf{n}$ & $\%$ & $\mathbf{n}$ & $\%$ \\
\hline 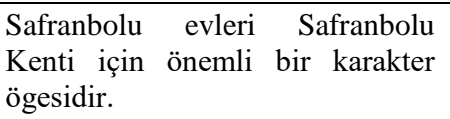 & 116 & 91.3 & 9 & 7.1 & - & - & - & - & 2 & 1.6 \\
\hline $\begin{array}{l}\text { Yeni yapılaşmalar tarihi kent } \\
\text { dokusu ile uyumludur. }\end{array}$ & 26 & 20.5 & 38 & 29.9 & 20 & 15.7 & 29 & 22.8 & 14 & 11 \\
\hline $\begin{array}{l}\text { Safranbolu geleneksel } \\
\text { dokusu mevcut haliyle kente } \\
\text { kültürel ve estetik bir görünüm } \\
\text { kazandırmaktadır. }\end{array}$ & 89 & 70.1 & 32 & 25.2 & 5 & 3.9 & 1 & 0.8 & - & - \\
\hline $\begin{array}{l}\text { Mevcut olan bağ yerleşimleri şu } \\
\text { an bakımsız ve terk edilmiş bir } \\
\text { haldedir. }\end{array}$ & 12 & 9.4 & 34 & 26.8 & 64 & 50.4 & 13 & 10.2 & 4 & 3.1 \\
\hline $\begin{array}{l}\text { Safran, Safranbolu } \\
\text { karakteristik bir bitkidir. }\end{array}$ & 71 & 55.9 & 32 & 25.2 & 21 & 16.5 & 2 & 1.6 & 1 & 0.8 \\
\hline $\begin{array}{lllr}\text { Üzüm bağları } & \text { ve } & \text { orkide } \\
\text { Safranbolu için } & \text { karakteristik } \\
\text { değerlerdir. } & & \end{array}$ & 21 & 16.5 & 34 & 26.8 & 59 & 46.5 & 13 & 10.2 & - & - \\
\hline $\begin{array}{l}\text { Tokatlı Kanyonu ve Tabakhane } \\
\text { Deresi Safranbolu Kenti için } \\
\text { önemli ekolojik ve estetik } \\
\text { alanlardır. }\end{array}$ & 64 & 50.4 & 42 & 33.1 & 20 & 15.7 & - & - & 1 & 0.8 \\
\hline $\begin{array}{l}\text { Kent dokusundaki mevcut açık ve } \\
\text { yeşil alanlar nitelik ve nicelik } \\
\text { yönünden yeterlidir. }\end{array}$ & 11 & 8.7 & 44 & 34.6 & 36 & 28.3 & 35 & 27.6 & 1 & 0.8 \\
\hline $\begin{array}{l}\text { Kültürel kimlik değişmeden } \\
\text { günümüze kadar ulaşmıştır. }\end{array}$ & 37 & 29.1 & 63 & 49.6 & 10 & 7.9 & 15 & 11.8 & 2 & 1.6 \\
\hline $\begin{array}{l}\text { Safranbolu'daki yerleşim dokusu } \\
\text { topoğrafya ile uyumludur. }\end{array}$ & 40 & 31.5 & 70 & 55.1 & 13 & 10.2 & 3 & 2.4 & 1 & 0.8 \\
\hline
\end{tabular}

Her üç kent için sorulan ortak sorular Frekans Analizi'ne göre değerlendirilmiștir. $\mathrm{Bu}$ sonuçlara göre; sadece Safranbolu'nun kent dokusundaki açık ve yeşil alanlar nitelik ve nicelik yönünden yeterlidir, sadece Bartın'ın kültürel kimliği değişerek günümüze ulaşmıştır ve her üç kentte de yerleşim dokusu topoğrafya ile uyumludur. Katılımcılar gelecekte, her üç kent için kültürel mirasın sürdürülebilirliğinin sağlanmasını, turizmde marka kent olma yolunda ilerlenmesini, kent kimliğine ve karakterine uygun planlama ve tasarım çalışmaları yapılması gerektiğini ve kentsel tasarımda açık ve yeșil alanların kent bütününde ilişkisinin sağlanmasını talep etmişlerdir (Tablo 5).

\section{Ki-Kare analizi bulguları}

SPSS programinda yapilan Ki-kare analizinde anlamlı ilişkisi saptanan karşılaştırmalar sonucunda elde edilen sonuçlar şu şekildedir:

- Sel ve taşkın riski açısından Bartın Çayı ve çevresinin yeniden planlanmas1 gerekmektedir ve kentsel tasarım uygulamalarında açık ve yeşil alanların kent bütününde ilişkisi sağlanmalıdır (Tablo 6).

- Bartın Çayı Bartın Kenti için önemli bir karakter ögesidir ve Bartın Çayı 
mevcut haliyle kente doğal ve estetik bir görünüm kazandırmaktadır (Tablo 6).

- Amasra'daki tescilli yapilar kent bütününde yeterince algılanmamaktadır ve kent kimliği değişmektedir (Tablo 7).

- Amasra turizmde bir marka kenttir ve gastronomi turizmi açısından önem taşımaktadır (Tablo 7).
- Safranbolu evleri Safranbolu Kenti için önemli bir karakter ögesidir ve kentin kültürel kimliği değişmemektedir (Tablo 8).

- Safranbolu'daki yerleşim dokusu topoğrafya ile uyumludur. Safranbolu geleneksel kent dokusu mevcut haliyle kente kültürel ve estetik bir görünüm kazandırmaktadır (Tablo 8).

Tablo 5. Bartın, Amasra ve Safranbolu için ortak olan soruların sonuçlarının karşılaştııılması Her üç kent için ortak olan sorular

Bartın

Amasra

\begin{tabular}{|c|c|c|c|c|c|c|}
\hline \multirow{2}{*}{$\begin{array}{l}\text { Kent dokusundaki açık ve yeşil alanlar nitelik ve } \\
\text { nicelik yönünden yeterlidir. }\end{array}$} & \multicolumn{2}{|c|}{ katılmiyorum } & \multicolumn{2}{|c|}{ katılmiyorum } & \multicolumn{2}{|c|}{ katıliyorum } \\
\hline & $\mathrm{n}: 47$ & $\%: 37$ & $\mathrm{n}: 44$ & $\%: 34.6$ & $\mathrm{n}: 44$ & $\%: 34.6$ \\
\hline \multirow{2}{*}{$\begin{array}{l}\text { Kültürel kimlik değişmeden günümüze kadar } \\
\text { ulaşmıştır }\end{array}$} & \multicolumn{2}{|c|}{ katılmiyorum } & \multicolumn{2}{|c|}{ kat1liyorum } & \multicolumn{2}{|c|}{ kat1liyorum } \\
\hline & n: 59 & $\%: 46.5$ & $\mathrm{n}: 51$ & $\%: 40.2$ & $\mathrm{n}: 63$ & $\%: 49.6$ \\
\hline \multirow[t]{2}{*}{ Yerleşim dokusu topoğrafya ile uyumludur. } & \multicolumn{2}{|c|}{ katıliyorum } & \multicolumn{2}{|c|}{ katıliyorum } & \multicolumn{2}{|c|}{ katıliyorum } \\
\hline & $\mathrm{n}: 43$ & $\%: 33.9$ & n: 67 & $\%: 52.8$ & $\mathrm{n}: 70$ & $\%: 55.1$ \\
\hline \multirow[t]{2}{*}{ Kültürel mirasın sürdürülebilirliği sağlanmalıdır. } & \multicolumn{2}{|c|}{$\begin{array}{l}\text { kesinlikle } \\
\text { kat1liyorum }\end{array}$} & \multicolumn{2}{|c|}{$\begin{array}{l}\text { kesinlikle } \\
\text { katıliyorum }\end{array}$} & \multicolumn{2}{|c|}{$\begin{array}{l}\text { kesinlikle } \\
\text { katıliyorum }\end{array}$} \\
\hline & n: 98 & $\%: 77.2$ & $\mathrm{n}: 113$ & $\%: 89$ & $\mathrm{n}: 112$ & $\%: 88.2$ \\
\hline \multirow[t]{2}{*}{$\begin{array}{l}\text { Turizmde marka kent olma yolunda } \\
\text { ilerlenmelidir. }\end{array}$} & \multicolumn{2}{|c|}{$\begin{array}{l}\text { kesinlikle } \\
\text { katıliyorum }\end{array}$} & \multicolumn{2}{|c|}{$\begin{array}{l}\text { kesinlikle } \\
\text { katıliyorum }\end{array}$} & \multicolumn{2}{|c|}{$\begin{array}{l}\text { kesinlikle } \\
\text { katıliyorum }\end{array}$} \\
\hline & n: 64 & $\%: 50.4$ & $\mathrm{n}: 108$ & $\%: 85$ & $\mathrm{n}: 88$ & $\%: 69.3$ \\
\hline \multirow[t]{2}{*}{$\begin{array}{l}\text { Kentin kimliğine ve karakterine uygun planlama } \\
\text { ve tasarım çalışmaları yapılmalıdır. }\end{array}$} & \multicolumn{2}{|c|}{$\begin{array}{l}\text { kesinlikle } \\
\text { katılıyorum }\end{array}$} & \multicolumn{2}{|c|}{$\begin{array}{l}\text { kesinlikle } \\
\text { katıliyorum }\end{array}$} & \multicolumn{2}{|c|}{$\begin{array}{c}\text { kesinlikle } \\
\text { kat1liyorum }\end{array}$} \\
\hline & n: 106 & $\%: 83.5$ & $\mathrm{n}: 110$ & $\%: 86.6$ & n: 101 & $\%: 79.5$ \\
\hline \multirow[t]{2}{*}{$\begin{array}{l}\text { Kentsel tasarımda açık ve yeşil alanların kent } \\
\text { bütününde ilişkisi sağlanmalıdır. }\end{array}$} & \multicolumn{2}{|c|}{$\begin{array}{l}\text { kesinlikle } \\
\text { katıliyorum }\end{array}$} & \multicolumn{2}{|c|}{$\begin{array}{l}\text { kesinlikle } \\
\text { kat1liyorum }\end{array}$} & \multicolumn{2}{|c|}{$\begin{array}{l}\text { kesinlikle } \\
\text { katıliyorum }\end{array}$} \\
\hline & n: 106 & $\%: 83.5$ & n: 103 & $\%: 81.1$ & $\mathrm{n}: 98$ & $\%: 77.2$ \\
\hline
\end{tabular}

Tablo 6. Bartın Kenti için yapılan Ki-Kare Test sonucu

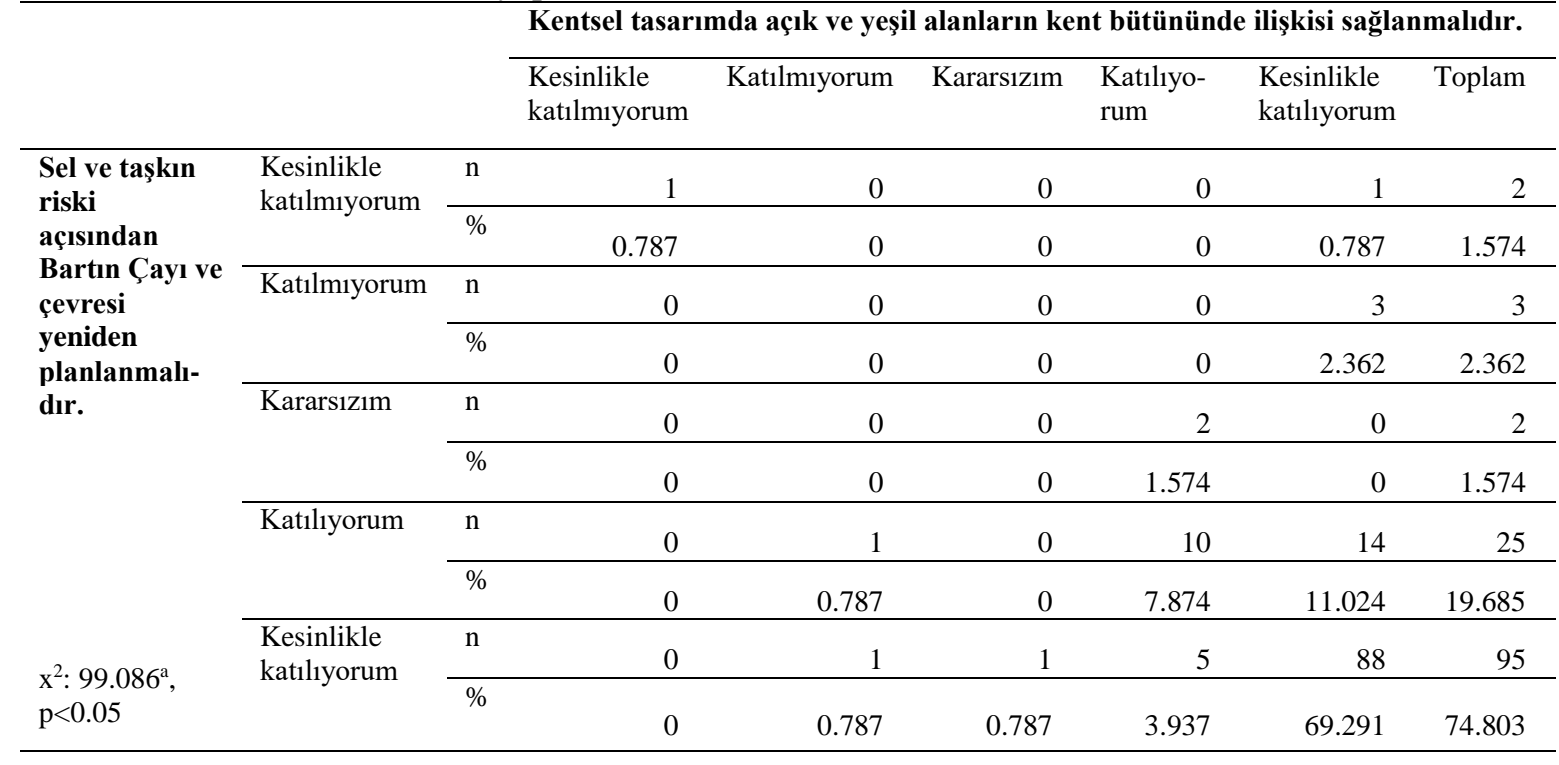


Tablo 6'nın devamı.

\begin{tabular}{|c|c|c|c|c|c|c|c|c|}
\hline \multirow{5}{*}{$\begin{array}{l}\text { Bartın Çayı } \\
\text { Bartın } \\
\text { Kenti için } \\
\text { önemli bir } \\
\text { karakter } \\
\text { ögesidir. }\end{array}$} & \multirow{3}{*}{$\begin{array}{l}\text { Kesinlikle } \\
\text { katılmıorum }\end{array}$} & \multirow[b]{2}{*}{$\mathrm{n}$} & \multicolumn{5}{|c|}{$\begin{array}{l}\text { Bartın Çayı mevcut haliyle kente doğal ve estetik bir görünüm } \\
\text { kazandırmaktadır. }\end{array}$} & \multirow[b]{2}{*}{1} \\
\hline & & & 0 & 0 & 1 & 0 & 0 & \\
\hline & & $\%$ & 0 & 0 & 0.787 & 0 & 0 & 0.787 \\
\hline & \multirow[t]{2}{*}{ Katılmiyorum } & $\mathrm{n}$ & 0 & 1 & 0 & 1 & 0 & 2 \\
\hline & & $\%$ & 0 & 0.787 & 0 & 0.787 & 0 & 1.574 \\
\hline & \multirow[t]{2}{*}{ Kararsızım } & $\mathrm{n}$ & 0 & 1 & 0 & 0 & 0 & 1 \\
\hline & & $\%$ & 0 & 0,787 & 0 & 0 & 0 & 0.787 \\
\hline \multirow{4}{*}{$\begin{array}{l}\mathrm{x}^{2}: 29.237^{\mathrm{a}} \\
\mathrm{p}<0.05\end{array}$} & \multirow[t]{2}{*}{ Katılıyorum } & $\mathrm{n}$ & 1 & 11 & 6 & 6 & 2 & 26 \\
\hline & & $\%$ & 0.787 & 8.661 & 4.724 & 4.724 & 1.574 & 20.472 \\
\hline & \multirow{2}{*}{$\begin{array}{l}\text { Kesinlikle } \\
\text { kat1lyyorum }\end{array}$} & $\mathrm{n}$ & 9 & 16 & 7 & 43 & 22 & 97 \\
\hline & & $\%$ & 7.086 & 12.598 & 5.512 & 33.858 & 17.323 & 76.377 \\
\hline
\end{tabular}

Tablo 7. Amasra Kenti için yapılan Ki-Kare Test sonucu

Kültürel kimlik değişmeden günümüze kadar ulaşmıştır.

\begin{tabular}{|c|c|c|c|c|}
\hline 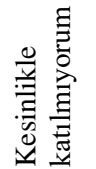 & 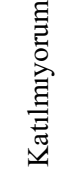 & 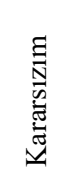 & 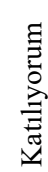 & 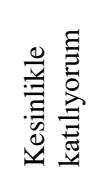 \\
\hline
\end{tabular}

\begin{tabular}{|c|c|c|c|c|c|c|c|c|}
\hline \multirow{6}{*}{$\begin{array}{l}\text { Tescilli yapılar } \\
\text { kent bütününde } \\
\text { yeterince } \\
\text { algılanmaktadır } \\
\text { (Amasra Kalesi, } \\
\text { Cenova Şatosu, } \\
\text { Kemere } \\
\text { Köprüsü, Şapel } \\
\text { vb.). }\end{array}$} & \multirow{2}{*}{$\begin{array}{l}\text { Kesinlikle } \\
\text { katılmıyorum }\end{array}$} & $\mathrm{n}$ & 4 & 2 & 2 & 2 & 0 & 10 \\
\hline & & $\%$ & 3.149 & 1.574 & 1.574 & 1.574 & 0 & 7.873 \\
\hline & \multirow[t]{2}{*}{ Katılmiyorum } & $\mathrm{n}$ & 3 & 10 & 8 & 11 & 0 & 32 \\
\hline & & $\%$ & 2.362 & 7.873 & 6.299 & 8.661 & 0 & 25.196 \\
\hline & \multirow[t]{2}{*}{ Kararsızım } & $\mathrm{n}$ & 0 & 1 & 8 & 3 & 1 & 13 \\
\hline & & $\%$ & 0 & 0.787 & 6.299 & 2.362 & 0.787 & 10.236 \\
\hline \multirow{4}{*}{$\begin{array}{l}\mathrm{x}^{2}: 51.391^{\mathrm{a}}, \\
\mathrm{p}<0.05\end{array}$} & \multirow[t]{2}{*}{ Kat1liyorum } & $\mathrm{n}$ & 2 & 10 & 6 & 20 & 2 & 40 \\
\hline & & $\%$ & 1.574 & 7.873 & 4.724 & 15.748 & 1.574 & 31.496 \\
\hline & \multirow[t]{2}{*}{$\begin{array}{l}\text { Kesinlikle } \\
\text { kat1lyyorum }\end{array}$} & $\mathrm{n}$ & 0 & 3 & 6 & 15 & 8 & 32 \\
\hline & & $\%$ & 0 & 2.362 & 4.724 & 11.811 & 6.299 & 25.196 \\
\hline
\end{tabular}

Amasra Kenti gastronomi turizmi açısından önem taşımaktadır.

\begin{tabular}{|c|c|c|c|c|c|c|c|c|}
\hline \multirow{6}{*}{$\begin{array}{l}\text { Amasra Kenti } \\
\text { turizmde bir } \\
\text { marka kenttir. }\end{array}$} & \multirow[t]{2}{*}{ Katılmıyorum } & $\mathrm{n}$ & 0 & 1 & 1 & 1 & 1 & 4 \\
\hline & & $\%$ & 0 & 0.787 & 0.787 & 0.787 & 0.787 & 3.149 \\
\hline & \multirow[t]{2}{*}{ Kararsızım } & $\mathrm{n}$ & 1 & 3 & 1 & 4 & 1 & 10 \\
\hline & & $\%$ & 0.787 & 2.362 & 0.787 & 3.149 & 0.787 & 7.873 \\
\hline & \multirow[t]{2}{*}{ Katıliyorum } & $\mathrm{n}$ & 3 & 3 & 10 & 22 & 7 & 45 \\
\hline & & $\%$ & 2.362 & 2.362 & 7.873 & 17.323 & 5.512 & 35.433 \\
\hline \multirow[t]{2}{*}{$\begin{array}{l}x^{2}: 42.903^{a} \\
p<0.05\end{array}$} & \multirow[t]{2}{*}{$\begin{array}{l}\text { Kesinlikle } \\
\text { katıliyorum }\end{array}$} & $\mathrm{n}$ & 1 & 2 & 13 & 27 & 25 & 68 \\
\hline & & $\%$ & 0.787 & 1.574 & 10.236 & 21.260 & 19.685 & 53.543 \\
\hline
\end{tabular}


Tablo 8. Safranbolu Kenti için yapılan Ki-Kare Test sonucu

\begin{tabular}{|c|c|c|c|c|c|c|c|c|}
\hline & & & \multicolumn{6}{|c|}{ Kültürel kimlik değişmeden günümüze kadar ulaşmıştır. } \\
\hline & & & 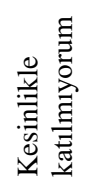 & 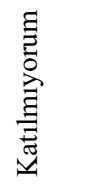 & 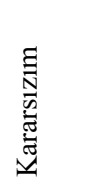 & 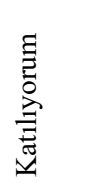 & 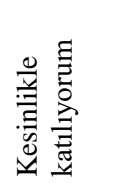 & $\begin{array}{l}\frac{\Xi}{\sigma} \\
\frac{0}{2} \\
\stackrel{0}{0}\end{array}$ \\
\hline \multirow{4}{*}{$\begin{array}{l}\text { Safranbolu evleri } \\
\text { Safranbolu Kenti için } \\
\text { önemli bir karakter } \\
\text { ögesidir. }\end{array}$} & \multirow{2}{*}{$\begin{array}{l}\text { Kesinlikle } \\
\text { katılmıyorum }\end{array}$} & $\mathrm{n}$ & 1 & 0 & 0 & 1 & 0 & 2 \\
\hline & & $\%$ & 0.787 & 0 & 0 & 0.787 & 0 & 1.574 \\
\hline & \multirow[t]{2}{*}{ Katıliyorum } & $\mathrm{n}$ & 1 & 4 & 1 & 3 & 0 & 9 \\
\hline & & $\%$ & 0.787 & 3.149 & 0.787 & 2.362 & 0 & 7.086 \\
\hline \multirow{3}{*}{$\mathrm{x}^{2}: 49.994^{\mathrm{a}}, \mathrm{p}<0.05$} & \multirow{2}{*}{$\begin{array}{l}\text { Kesinlikle } \\
\text { kat1lyyorum }\end{array}$} & $\mathrm{n}$ & 0 & 11 & 9 & 59 & 37 & 116 \\
\hline & & $\%$ & 0 & 8.661 & 7.086 & 46.457 & 29.134 & 91.338 \\
\hline & & & \multicolumn{6}{|c|}{ Safranbolu'daki yerleşim dokusu topografya ile uyumludur. } \\
\hline \multirow{4}{*}{$\begin{array}{l}\text { Safranbolu geleneksel } \\
\text { kent dokusu mevcut } \\
\text { haliyle kente kültürel ve } \\
\text { estetik bir görünüm } \\
\text { kazandırmaktadır. }\end{array}$} & \multirow{2}{*}{$\begin{array}{l}\text { Katılmiyo- } \\
\text { rum }\end{array}$} & $\mathrm{n}$ & 0 & 1 & 0 & 0 & 0 & 1 \\
\hline & & $\%$ & 0 & 0.787 & 0 & 0 & 0 & 0.787 \\
\hline & \multirow[t]{2}{*}{ Kararsızım } & $\mathrm{n}$ & 1 & 0 & 1 & 2 & 1 & 5 \\
\hline & & $\%$ & 0.787 & 0 & 0.787 & 1.574 & 0.787 & 3.937 \\
\hline & Kat1lyyorum & $\mathrm{n}$ & 0 & 1 & 4 & 21 & 6 & 32 \\
\hline \multirow{3}{*}{$x^{2}: 70.937^{a}, p<0.05$} & & $\%$ & 0 & 0.787 & 3.149 & 16.535 & 4.724 & 25.196 \\
\hline & \multirow{2}{*}{$\begin{array}{l}\text { Kesinlikle } \\
\text { kat1lyyorum }\end{array}$} & $\mathrm{n}$ & 0 & 1 & 8 & 47 & 33 & 89 \\
\hline & & $\%$ & 0 & 0.787 & 6.299 & 37.008 & 25.984 & 70.078 \\
\hline
\end{tabular}

\section{Sonuç ve Değerlendirme}

Günümüzde yaşanan plansız ve hizlı kentleşme nedeniyle kentsel kültürel peyzaj karakteri zamanla değişmekte, homojenleşmekte ve kimliksizleşmektedir. Geleneksel dokuyla uyumlu olmayan yeni yapılaşmalar peyzaj karakterlerini olumsuz yönde etkilemektedir. Görsel peyzaj alg1 çalışmaları ile kentsel kültürel peyzajdaki değişimin değerlendirilmesi, kentsel planlama ve tasarım stratejilerinin geliştirilmesinde etkili rol oynamaktadır. Bu çalışmada Bartın, Amasra ve Safranbolu'daki kentsel kültürel peyzajlarda karakter ve alg1 değişimi üniversite öğrencilerine anket çalışması yapılarak uygulanmıştır.

Bartın Üniversitesi Peyzaj Mimarlığ1 Bölümü lisans ve lisansüstü öğrencilerine uygulanan anket sonuçları aşağıdaki şekilde özetlenmiştir:

- $\quad$ Öğrencilerin, seçilen kentler kapsamında kültürel peyzajlardaki karakter değişimindeki farkındalık düzeylerinin yüksek olduğu saptanmıştır. Bizerril (2004) ve
Hunziker ve ark. (2008) yaptığ1 çalışmalara paralel olarak peyzajla daha çok ilgilenen ve bu konu ile ilgili daha fazla ders almış olan öğrencilerin farkındalıklarının daha yüksek olduğu görülmüştür.

- Öğrencilerin seçilen kentler kapsamında gerek doğal gerekse kültürel peyzaj karakter ögelerini kent bütününde değerlendirmişlerdir.

- Safranbolu kentsel peyzaj karakter ögelerine ilişkin öğrencilerin farkındalık düzeylerinin yüksek olduğu ve kentsel kültürel kimlik ögelerinin günümüze kadar sürdürülebilir bir şekilde ulaştığ saptanmıştır.

- Bartın kenti için Bartın Çayı ve tarihi Bartın evleri önemli bir karakter ögesi olarak algilanmaktadır.

- Amasra kenti için doğal ve kültürel yap1 birbirini tamamlayan karakter ögeleri olarak ifade edilmiştir.

- Bartın, Amasra ve Safranbolu kentlerinde, gerek bakımsızlık gerekse 
tarihi dokuyla uyumsuz planlamalar ve tasarımlar açısından kentsel kültürel peyzaj karakterinin geçmişten günümüze olumsuz bir değişim süreci sergilediği katılımcı değerlendirmeleri sonucunda elde edilmiştir.

Araştırma alanlarındaki özgün peyzaj karakterleri Bartın, Amasra ve Safranbolu kentlerinin turizm potansiyeline olumlu katk1 sağlamakta ve bölge ekonomisini uzun dönemde canlandırması açısından önem teşkil etmektedir. $\mathrm{Bu}$ kapsamda, Kapuci (2004)'nin yaptığ 1 çalışma ile benzer sonuçlar ortaya çıkmaktadır.

Kent kimliğine ve peyzaj karakterine uygun gelecekte yapilacak planlama ve tasarım çalışmalarında kullanıcı algısına başvurulması kentsel kültürel peyzajların miras alanı olarak sürdürülebilirliği ve kentlerin okunabilirliği açısından önem taşımaktadır. Bu çalışma, peyzaj mimarlığı öğrencilerinin aldıkları eğitimin, mesleki alanlardaki farkındalı düzeylerini destekleyici bir rol oynadığını göstermektedir. Bu bağlamda, çalışma, yapı ölçeğinden kent ölçeğine kadarki kentsel tasarım stratejilerinin geliştirilmesi açısından önemli bir altlık niteliğindedir.

\section{Teșekkür}

İstatistiki değerlendirmelerde katkıda bulunan Bartın Üniversitesi Fen Fakültesi İstatistik Bölümü Bölüm Başkanı Sayın Yrd. Doç. Dr. Bahar BAŞKIR'a teşekkür ederiz.

\section{Kaynaklar}

Ak, M. K., 2013. Visual quality assessment methods in landscape architecture studies. Advances in Landscape Architecture (Ed. M. Ozyavuz), InTech Open Access Publisher, 279290.

Antrop, M., 2004. Landscape change and the urbanization process in Europe. Landscape and Urban Planning, 67, 9-26.

Bürgi, M., Hersperger, A.M., Schneeberger, N., 2004. Driving forces of landscape change current and new directions. Landscape Ecology, 19, 857-868.

Bulut, Z., Y1lmaz, H., 2008. Determination of landscape beauties through visual quality assessment method: a case study for Kemaliye (Erzincan/Turkey). Environmental Monitoring and Assessment, 141 (1-3), 121-129.
Can, A., 2014. SPSS ile bilimsel araştırma sürecinde nicel veri analizi. ISBN:978-605-364448-4, 389 s, Pegem Akademi Yayınları, Ankara.

Cengiz, B., 2007. Bartın Çayı peyzaj özelliklerinin saptanması ve değerlendirilmesi üzerine bir çalışma. Doktora Tezi, Ankara Üniversitesi, Fen Bilimleri Enstitüsü, Peyzaj Mimarlığ 1 Anabilim Dalı, 291 s. Ankara.

Cengiz, B., Cengiz, C., 2016. Amasra tarihi kent dokusu ve yakın çevresinin kültürel peyzaj açısından değerlendirilmesi, I. Ulusal Ankara Üniversitesi Peyzaj Mimarlığg Kongresi, Yerel Peyzajlar ve Koruma Sorunları (15-17 Ekim 2015), 143-154, Ankara, Türkiye.

Cengiz. C., Aşkın. F.K. 2015. Ecological urban design for traditional Turkish settlement in Safranbolu, Turkey. Fresenius Environmental Bulletin, 24 (10a), 3240-3257.

Cengiz, C., Keçecioğlu, P., 2014. Evaluation of urban identification elements in terms of urban design and urban image: A case study of Amasra, Turkey. 2nd International Symposium on Environment \& Morality, ISEM 2014 (24-26 October 2014), 544-554, Adiyaman, Turkey.

Çetinkaya, G., Uzun, O., (2014). Peyzaj Planlama. ISBN:978-975-511-608-2, 219 s, Birsen Yayınevi, İstanbul

EHLA, 2014. Tarihi peyzaj ve kültürel mirasın değerlendirilmesi çalıştayı özet raporu, İstanbul Teknik Üniversitesi Matbaası, İstanbul.

Erdoğan, E., 2006. Çevre ve kent estetiği. ZKÜ Bartın Orman Fakültesi Dergisi, 8 (9), 6877.

Hunziker, M., Felber, P., Gehring, K., Buchecker, M., Bauer, N., Kienast, F., (2008). Evaluation of landscape change by different social groups. Mountain Research and Development, 28 (2), 140-147.

Kapuci, C., 2004. Tarihi kent dokusunun turizm potansiyeline etkisi: İznik kenti örneği. Yüksek Lisans tezi. Zonguldak Karaelmas Üniversitesi, Fen Bilimleri Enstitüsü, Peyzaj Mimarlığı Anabilim Dalı, 298 s. Zonguldak.

Kurtar, C., Somuncu, M., 2013. Kentsel kültürel mirasın korunması ve sürdürülebilirliği: Ankara Hamamönü örneği. Ankara Araştırmaları Dergisi, 1 (2), 35-47.

Nassauer, J.I., 1995. Culture and changing landscape structure. Landscape Ecology, 10 (4), 229-237.

Şahin, Ş., Perçin, H., Kurum, E., Uzun, O., Bilgili, B. C. 2013. Bölge- alt bölge (il) ölçeğinde peyzaj karakter analizi ve değerlendirmesi ulusal teknik klavuzu. ISBN: 978-605-136-201-4, 123 s, Elma Teknik Basım Matbaacılık, Ankara.

Tudor, C., 2014. An approach to landscape character assessment, 
https://www.gov.uk/government/uploads/system/ uploads/attachment_data/file/396192/landscapecharacter-assessment.pdf, 01.10.2015

Türker, N., Çetinkaya, A., 2009. Batı Karadeniz Bölümü ekoturizm potansiyeli. ISBN:978-605-89395-0-9, 630 s, Detay Yayıncilık, Ankara

Tveit, M., Ode, A., Fry, G., 2006. Key concepts in a frame for analysing visual landscape character. Landscape Research, 31, 229-255.

UNESCO 2011. "Recommendation on The Historic Urban Landscape, Including a Glossary of Definitions", http://portal.unesco.org/en/ev.phpURL_ID $=23772 \& U R L \_D O=D O \_T O P I C \& U R L$ SECTION=201.html\#, 22.01.2015

URL1.http://www.cevre.org.tr/Tcm/Sozlesmel er/Avrupa\%20Peyzaj\%20Sozlesmesi.htm, 15.12.2015
URL2.

http://www.safranbolu.gov.tr/default_B0.aspx?co ntent $=47,22.10 .2015$

URL3.http://www.tarihikentlerbirligi.org/etki nlikler/anadolu-bulusmalari/bulusmalar-listesi/, 20.09.2015

URL4.

http://whc.unesco.org/en/tentativelists/state=tr, 20.09.2015

*Yazar Notu: Bu çalışma 13-14 Kasım 2015 tarihinde Kocaeli'nde düzenlenen " 1 st International Congress on Engineering, Architecture and Design" başlıklı kongrede sözlü bildiri olarak sunulmuş (İngilizce) ve bildiri kitabında özet (abstract) olarak basılmıştır. 